University of Chicago Law School

Chicago Unbound

Public Law and Legal Theory Working Papers

Working Papers

2008

\title{
Erga Omnes Norms, Institutionalization, and Constitutionalism in International Law
}

Eric A. Posner

Follow this and additional works at: https://chicagounbound.uchicago.edu/public_law_and_legal_theory

Part of the Law Commons

Chicago Unbound includes both works in progress and final versions of articles. Please be aware that a more recent version of this article may be available on Chicago Unbound, SSRN or elsewhere.

\section{Recommended Citation}

Eric Posner, "Erga Omnes Norms, Institutionalization, and Constitutionalism in International Law " (University of Chicago Public Law \& Legal Theory Working Paper No. 224, 2008).

This Working Paper is brought to you for free and open access by the Working Papers at Chicago Unbound. It has been accepted for inclusion in Public Law and Legal Theory Working Papers by an authorized administrator of Chicago Unbound. For more information, please contact unbound@law.uchicago.edu. 


\title{
CHICAGO
}

John M. Olin LAW \& ECONOMics WORKING PAPER No. 419

(2D SERIES)

Public LaW and Legal Theory Working Paper No. 224

\section{ERGA OMNES NORMS, INSTITUTIONALIZATION, AND \\ CONSTITUTIONALISM IN INTERNATIONAL LAW}

\author{
Eric A. Posner
}

\section{THE LAW SCHOOL THE UNIVERSITY OF CHICAGO}

August 2008

This paper can be downloaded without charge at the John M. Olin Program in Law and Economics Working Paper Series: http://www.law.uchicago.edu/Lawecon/index.html and at the Public Law and Legal Theory Working Paper Series: http://www.law.uchicago.edu/academics/publiclaw/index.html and The Social Science Research Network Electronic Paper Collection. 


\title{
Erga Omnes Norms, Institutionalization, and Constitutionalism in International Law
}

\author{
ERIC A. POSNER ${ }^{*}$
}

\begin{abstract}
Erga omnes norms are those that give third-party states, rather than just the victim, legal claims against states that violate them. This paper argues that ordinary twoparty norms arise when states recognize that a norm violation injures only one state and that other states that seek to retaliate on that state's behalf are likely using the violation as a pretext for predatory behavior. Erga omnes norms arise when states recognize that a norm violation injures multiple states and that states have an incentive to free ride rather than retaliate against the violator. Erga omnes norms reduce the incentive to free ride but at the same time reintroduce the risk that some states will use a norm violation as a pretext for engaging in predatory behavior.
\end{abstract}

\section{Introduction}

International law scholars distinguish between ordinary or two-party norms and "erga omnes" norms. Both types of norms proscribe activity; the difference between them concerns enforcement. If state $X$ engages in activity that violates an ordinary norm and state $Y$ is injured by that activity, only state $Y$ has a legal claim against $X$, and hence only state $Y$ has the right to engage in countermeasures against $Y$. If state $X$ engages in activity that violates an erga omnes norm, all states have legal claims against $X$, and hence all states have the right to engage in countermeasures.

Careful scholarship has identified only a handful of clear erga omnes norms, but there are many likely candidates. ${ }^{1}$ The four clear examples are the laws against aggression, genocide, slavery, and racial discrimination. It seems plausible that other human rights are erga omnes norms; these could include laws against torture, sex discrimination, and arbitrary detention. Certain norms against pollution might also be erga omnes norms.

\footnotetext{
* Thanks to conference participants and especially Christoph Engel and Alexander Stremitzer, and to Mitu Gulati, Richard McAdams, and Alan Sykes, for helpful comments.

${ }^{1}$ See, e.g., Maurizio Ragazzi, The Concept of International Obligations Erga Omnes (Oxford 1997); Karl Zemanek, New Trends in the Enforcement of Erga Omnes Obligations, 4 Max Planck UNYB 1 (2000).
} 
Why do some international legal norms have the status erga omnes while others do not? This paper argues that two-party norms arise when states recognize that a norm violation injures only one state and that other states that seek to retaliate on that state's behalf are likely using the violation as a pretext for predatory behavior. Erga omnes norms arise when states recognize that a norm violation injures multiple states and that states have an incentive to free ride rather than retaliate against the violator. Erga omnes norms reduce the incentive to free ride but at the same time reintroduce the risk that some states will use a norm violation as a pretext for engaging in predatory behavior. The analysis is extended to the case of institutionalization and constitutionalization of international norms, and to the role of NGOs in international legal relations.

\section{Two-Party Norms}

\subsection{The Model}

The simplest relationship in international law is the relationship between two states. Imagine two states, $X$ and $Y$, which share a common border. If state $X$ and $Y$ act like most states, then their relationship will contain a mixture of cooperation and rivalry. To keep things simple, suppose that $X$ and $Y$ do not cooperate or compete in any way except with respect to the border. The government of each state chooses either to respect the border or to attempt to push it farther back-by sending troops or civilians into the territory on the other side. Respecting the border is a cooperative act; attempting to push it back is a competitive or predatory act.

We can easily picture this relationship in game theoretic terms. Suppose that only state $X$ is in the position to act in a predatory fashion. In round 1, $X$ may choose not to act (in which case the game ends and the status quo is maintained) or to act aggressively (by sending troops across the border to secure territory on the other side). In round 2, $Y$ chooses to threaten to retaliate or not to threaten to retaliate. If $Y$ does not threaten to retaliate, the game ends with a high payoff for $X$ and a low payoff for $Y$. If $Y$ threatens to retaliate, $X$ can either withdraw and pay reparations or refuse to do so. In round 3 , if $X$ withdraws ("provides a remedy"), the game ends. $Y$ has the status quo payoff, while $X$, which has launched a failed invasion, is worse off. Finally, in round 4, $Y$ retaliates or 
backs down. If $Y$ retaliates, both parties suffer heavy losses, ending up worse than in the status quo. If $Y$ backs down, then $X$ gains at $Y$ 's expense.

Clearly, in the one-shot version of this game, $X$ invades and $Y$ backs down. In the repeated version, a possible equilibrium is one in which $Y$ threatens to retaliate if $X$ invades and retaliates if $X$ does not provide a remedy, and $X$ does not invade and pays a remedy if it does invade (off the equilibrium path). $Y$ would need a sufficiently low discount rate for such an equilibrium to be possible.

In this equilibrium, we can say that there is "norm" against invading or crossing the border. The norm is entirely endogenous, the result of the two states adopting strategies that are sustainable in an equilibrium. In practice, the norm might come about spontaneously; or it might be the result of a treaty. In the first case, the states would refer to the norm as customary international law.

Finally, suppose that there exists a third state, $Z$. When $X$ injures $Y$, it does not also injure state $Z$. But we might imagine that $Z$ threatens to retaliate against $X$ on account of the injury to $Y$. Why would $Z$ do this? $Z$ might have an independent reason for harming $X$; or perhaps $Z$ hopes that $X$ will bribe $Z$ not to retaliate. However, there is no reason to think that $Z$ gains anything by claiming that its threats against $X$ are due to $X$ 's conduct with respect to $Y$. If $Z$ is powerful enough to adjust its relationship with $X$ so as to improve its own position, then $Z$ would do that independently of $X$ 's behavior toward $Y$. If $Z$ is not, then $X$ 's behavior toward $Y$ does not change this. Accordingly, it is reasonable to say that $X$ and $Y$ 's relationship is governed by a two-party norm, one that prohibits $X$ from preying on $Y$, and also that prohibits $Z$ from taking action against $X$ if $X$ fails to observe the prohibition on predation against $Y$.

The analysis can be easily extended to cover any form of international bilateral cooperation. $X$ 's predatory behavior could be the release of pollution that crosses the border; the mistreatment of $Y$ 's diplomats located on $X$ 's territory; the mistreatment of any of $Y$ 's citizens who cross the border; the erection of tariffs or other barriers despite a treaty or custom of free trade; harassment of $Y$ 's citizens on the high seas or in foreign countries; the denial of overflight rights despite a treaty that establishes them; and so forth. In all cases, the norms come into existence because they reflect mutually beneficial 
cooperative arrangements; violation is simply deviation from the norms that reflect those arrangements.

\subsection{The Limits}

Why would violation ever occur? We can distinguish three major reasons.

First, an exogenous shock changes one or both states' payoffs, rendering a mutually beneficial arrangement harmful for one or both states. Suppose an economic downturn creates a political reaction against free trade in State $X$. $X$ 's government no longer believes that $X$ benefits from the trade relationship, and accordingly raises tariff barriers. At this point, an important ambiguity is introduced. One could say that $X$ violated the norm, but one could just as easily say that the norm has changed. If circumstances have changed permanently, there is no possibility that the original norm will come back into existence.

Second, the government of one state might miscalculate. Suppose that the government of $X$ believes that $Y$ will not retaliate if it sends troops across the border. $X$ 's government might believe that $Y$ 's government is, perhaps temporarily, too weak. If $X$ 's government subsequently realizes its error after acting, perhaps because $Y$ issues a credible threat of retaliation backed by a mobilized force, $X$ 's government will rationally back down. Paying reparations will help reestablish the original, mutually beneficial norm. $^{2}$

Third, the discount factor of one government declines-also the result of an exogenous shock. Suppose that $Y$ 's constitutional regime collapses as a result of internal discontent, and so it can no longer credibly threaten to retaliate after $X$ violates a norm. $X$ will then violate the norm. $Y$, from a position of weakness, will have to negotiate a new norm (perhaps a new border, for example, or disadvantageous trade relations). From that point, the relationship can continue.

As for $Z$, one can readily infer that $Z$ would violate the norm against using $X$ 's violation against $Y$ as a pretext for engaging in predatory behavior against $X$, for similar reasons. It would nonetheless be odd for $Z$ to claim that its conduct was actually an effort to act on Y's behalf; no one would believe it. There is also no reason to think that if $Z$ 's

\footnotetext{
2 This is an asymmetric information argument, not included in the model.
} 
relationship with $X$ broke down for those reasons, $Z$ 's predation would coincide with $X$ 's violation against $Y .1$

Still, in a more complicated setting, where there is uncertainty about Z's motives and about the nature of $X$ 's and $Z$ 's relationship, it would not be surprising if $Z$ tried to argue that it attacked $X$ on behalf of $Y$-or would try, if such a statement were credible. But because it is not in Z's self-interest to attack $X$ if and only if $X$ attacks $Y$, such a statement would not be credible. Z's statement would not be credible because it presupposes that $Z$ would act against its self-interest when everyone assumes that $Z$ acts in its self-interest. Or, in other words, $Z$ 's attack on $X$ (even if, somehow, in good faith) would violate a norm.

So far, we have explained how an international system exists, where states can have cooperative relationships. These relationships give rise to norms, some of which are refined and incorporated in treaties, others of which remain customary. The norms can exist only as long as the conditions of equilibrium exist. Exogenous shocks-chiefly, to payoffs or to discount factors-will cause states to change their strategies, resulting in changes in norms or their collapse.

\subsection{The Law}

The International Law Commission has set out several pertinent rules on the baseline case of two-state violation. Article 42 provides:

Invocation of responsibility by an injured State

A State is entitled as an injured State to invoke the responsibility of another State if the obligation breached is owed to:

(a) That State individually; or

(b) A group of States including that State, or the international community as a whole, and the breach of the obligation:

(i) Specially affects that State; or

(ii) Is of such a character as radically to change the position of all the other States to which the obligation is owed with respect to the further performance of the obligation. 
The rule provides that only the victim state can retaliate against the violator, except in the narrow case where the victim state acts as the agent of a group of states if the violation effects a radical change. $Z$ 's claim-that it is attacking $X$ in order to defend $Y$-is off limits.

Article 49 provides:

Object and limits of countermeasures

1. An injured State may only take countermeasures against a State which is responsible for an internationally wrongful act in order to induce that State to comply with its obligations under part two.

2. Countermeasures are limited to the non-performance for the time being of international obligations of the State taking the measures towards the responsible State.

3. Countermeasures shall, as far as possible, be taken in such a way as to permit the resumption of performance of the obligations in question.

Article 49 confirms that only the victim state $(Y$, not $Z)$ can retaliate. It also anticipates a resumption of the cooperative relationship. Thus, the model captures the legal notion that violations as between states generally assume an underlying cooperative relationship that has been ruptured but can also be repaired.

Let me summarize the relationship between the law and the model. The model assumes that states act in their self-interest. The relevant question is whether a particular act is cooperative or predatory. States would always like other states to see their acts as cooperative rather than predatory, because predatory acts may be met with retaliation, whereas cooperative acts will not. Any kind of violence, or deprivation of benefits, or disruption of a cooperative relations, may be seen as predatory unless the state can advance a good reason that the act is retaliation rather than predation.

\section{Erga Omnes Norms}

\subsection{The Model}

Suppose that there are three states, $X, Y$, and $Z$. $X$ and $Y$ have the relationship as described in Part I. Let $Z$ be a third state that borders $X$ and $Y$, and let $X$ and $Z$, and $Y$ and 
$Z$, have the same type of relationship that $X$ and $Y$ have. In effect, each state simultaneously plays two games, in each of which it can choose to respect or violate the border with one of the other states.

It is straightforward that an equilibrium exists in which each state respects the two borders. Such an equilibrium is possible as long as all three states have sufficiently high discount factors. Note that the norms that exist in this equilibrium are two-party norms, that is, the same type that existed in the original version of the game.

Let us add a fifth round to the original game. Recall that in round 4, $Y$ chooses to retaliate or not to retaliate. Let us add that if $Y$ does not retaliate, the game ends. If $Y$ retaliates the game proceeds to round 5 . In round $5, Z$ chooses to retaliate against $X$ (on $Y$ 's behalf) or not to retaliate. If $Z$ retaliates, $Z$ incurs a cost and $X$ incurs an additional cost. If $Z$ does not retaliate, $Z$ incurs no cost, while $X$ receives its round 4 payoff.

It is clear that $Y$ benefits if $Z$ chooses to retaliate in round 5. If, for example, $Y$ is too weak to sufficiently harm $X$ for violating the norm, then the prospect of retaliation by $Z$ might be all that will deter $X$ from violating the norm.

However, $Z$ has no incentive to retaliate in round $5 . Z$ incurs a cost and obtains no benefit. In order to explain why $Z$ would retaliate, one must assume that $Z$ is harmed by $X$ 's invasion of $Y$; $Z$ has a high discount factor; and therefore $Z$ benefits by deterring $X$ from invading $Y$. There are, in fact, several ways that $Z$ might benefit.

First, $Z$ might benefit because it fears that $X$ will become stronger as a result of its victory over $Y$ and subsequently pose a threat to $Z$. If $X$ becomes overwhelmingly strong, then in future $Z$ will become vulnerable to $X$ 's predation. For traditional balance-ofpower reasons, $Z$ would come to $Y$ 's aid.

Second, Z might benefit because of a moral externality. Z's public feels sympathy toward $X$ 's public, and pressures the government to respond. In effect, $X$ 's invasion of $Y$ inflicts a harm on $Z$, albeit of a psychological kind.

Third, $Z$ might benefit by sending a signal about its view about the norm that governs the relationship between $X$ and $Y$. This third explanation is more complicated than the first two. With respect to the first two, we can easily change the model to allow for $Z$ to incur a cost when $X$ invades $Y$. If $Z$ has a high enough discount factor, it will retaliate in round 5 , so as to deter such invasions. The benefit from sending a signal is 
that it clarifies the strategies that states will adopt in response to transgressions. I will say more about this argument in Section B, below.

Now, the key question is how $X$ will react to $Z$ 's retaliation. One can imagine two possible scenarios. In one scenario, $X$ regards $Z$ 's retaliation as an independent transgression-as though $Z$ had simply decided to invade $X$ for reasons independent of $X$ 's invasion of $Y$. In the other scenario, $X$ regards $Z$ 's retaliation as a response to $X$ 's invasion of $Y$. In either case, in round 6, $X$ might retaliate against $Z$ or back down.

There is a possible equilibrium in which $X$ does not invade $Y$ and (off the equilibrium path) $Y$ threatens to retaliate and does so if $X$ does not back down; $Z$ retaliates if $X$ does not back down; and $X$ does not retaliate in response to $Z$ 's retaliation. The norm - not to invade - is sustained by the possibility of third-party retaliation which is accepted as "legitimate" (that is, does not provoke further retaliation).

It is important for both $X$ and $Z$ that $X$ be able to distinguish between the scenario where $Z$ retaliates because of $X$ 's norm violation and the scenario where $Z$ independently transgresses a two-party norm. Regardless of the case, $Z$ will always claim that the second scenario obtains. If the setting is one in which it is plausible that $X$ 's act does injure $Z$ (for any of the three reasons discussed above), then $X$ may well perceive $Z$ 's act as retaliation and back down. If, however, the setting is more like the first scenario, then $X$ will see Z's act as an independent act and retaliate, disrupting their relationship.

In a setting where the first scenario is more likely-where $X$ 's norm violation against $Y$ is likely to hurt third parties as well, which retaliate in kind-the norm in question is likely to be regarded as erga omnes. $X$ 's initial invasion of $Y$ entitles $Y$ to retaliate and third parties such as $Z$ to retaliate; the retaliation by both parties are seen as retaliatory responses to $X$ 's transgression rather than as independent transgressions of a norm.

\subsection{The Limits}

The forms of cooperation that appear as erga omnes norms in the model are not bilateral but multilateral. The balance of power theory says that $X$ 's invasion of $Y$ creates a potential threat for $Z$-and, presumably, for other countries so far not included in the 
model. Thus, all countries potentially threatened by $X$ benefit from $Z$ 's response to $X$ 's transgression.

The moral externality theory says that $X$ 's invasion of $Y$ creates a moral harm suffered by $Z$-and, again, other countries, at least to the extent that people in those countries object to the harm caused by $X$ 's invasion. Thus, all countries harmed by the moral externality benefit from Z's response.

Finally, the signaling theory says that $X$ 's invasion of $Y$ muddies the norm. Here, we must say more about how this problem might arise.

If $n$ states exist, then there are $n ! /[2(n-2) !]$ pairwise interactions, in all of which one state might invade the other (though in many cases, this will not be practical). In the earlier models, we assumed that the norm is clear. $X$ 's action is clearly identifiable as a violation or not, both to $Y$ and to $Z$. In practice, it will often be unclear whether a particular action violates the norm or not-in part, because states will often benefit by engaging in actions whose status is ambiguous.

Suppose that, instead of launching an invasion of $Y, X$ did one of the following things: it sent spies onto $Y$ 's soil; it permitted loyal citizens of $X$ to voluntarily migrate to $Y$; it encouraged or subsidized such a migration; it placed a mobilized army on the border with $Y$; it permitted or encouraged factories on $X$ 's territory to send pollution in the direction of $Y$ 's territory; it sends police over the border to capture a fleeing criminal.

We could imagine any of these actions to be defined as transgressions or not; everything depends on whether $Y$ retaliates or not, which itself depends on the payoffs. Suppose, for example, that as a matter of treaty and custom, permitting migration over the border is not the violation of a norm. State $X$, however, goes farther and pays citizens to migrate, hoping to build up a community of pro- $X$ residents in $Y$ 's territory. $Y$ retaliates in some way. The question for $Z$ is whether it believes that it does best if it and its neighbors can subsidize migration or not. If the latter, it may well join with $Y$ in protesting $X$ 's action, hoping to establish a pattern of conduct that reinforces $Z$ 's interests.

The important thing to understand about all three theories is that they convert the original model of bilateral cooperation into a model of public-good creation involving multiple states. Not just $Y$ but many states have an interest in: preventing $X$ from 
obtaining power through conquest, seeing that people are not harmed in war, and clarifying the norms of conduct.

If this is true, then $Z$ may well not have an incentive to protect its interest but instead to do nothing in the hope that others will act instead. Third party enforcement introduces a collective action problem. Third party enforcement will occur if $Z$ or another state has a strong enough interest to intervene by itself. For example, suppose that $Z$ alone is worried about $X$ 's increasing power, or only Z's citizens feel the sting of the moral externality; then $Z$ might act alone because the gains are greater than the costs, and because it does not expect other states to act. Third party enforcement could also occur if various states, perhaps a subset of all states, can manage to enter an enforceable cooperative arrangement-which is more likely, the smaller the subset.

In sum, an erga omnes norm exists when other states retaliate against a violation of a norm that injures a particular state. In effect, the transgressor's act, though apparently injuring only one state, in fact injures multiple states, so a multi-state reaction can be expected. The injury is indirect, or at least not as clearly visible, but it is still real. The free-riding problem limits the likelihood of such a multi-state reaction, but it will nonetheless occur when individual states, or a small group of states, have enough at stake. The states with the most at stake-the highest benefits and lowest costs from intervention-will take the lead and sometimes even act alone.

The effect of an erga omnes norm is to make it easier for $Z$ to claim that its action against $X$ is retaliation rather than predation. $X$ itself, and other states, will not necessarily believe $Z$; but they are more likely to believe $Z$ than in the two-state case, where $Z$ has no right to retaliate, and so any action against $X$ is automatically treated as an independent violation. The corresponding danger is that when $X$ violates an erga omnes norm, $Z$ will retaliate, or threaten to retaliate, even though it has not been injured by the violation. Thus, erga omnes norms reduce the free-riding problem but increase the risk of predation.

We might therefore predict that erga omnes norms are most likely to arise when the free-riding problem is most acute and the predation risk is most limited. The freeriding problem increases in severity with the number of states that are injured; thus, the best case for an erga omnes norm occurs when all states are injured by the conduct in 
question. The predation risk is lowest when the norm in question identifies behavior that is deeply objectionable rather than potentially a matter of indifference to some states.

\subsection{The Law}

The ILM rules do not use the term “erga omnes” but the concept is clearly laid out in two articles. Article 48 provides:

Invocation of responsibility by a State other than an injured State

1. Any State other than an injured State is entitled to invoke the responsibility of another State in accordance with paragraph 2 if:

(a) The obligation breached is owed to a group of States including that State, and is established for the protection of a collective interest of the group; or

(b) The obligation breached is owed to the international community as a whole.

2. Any State entitled to invoke responsibility under paragraph 1 may claim from the responsible State:

(a) Cessation of the internationally wrongful act, and assurances and guarantees of non-repetition in accordance with article 30; and

(b) Performance of the obligation of reparation in accordance with the preceding articles, in the interest of the injured State or of the beneficiaries of the obligation breached.

3. The requirements for the invocation of responsibility by an injured State under articles 43, 44 and 45 apply to an invocation of responsibility by a State entitled to do so under paragraph 1.

Article 54, on countermeasures, provides:

This chapter does not prejudice the right of any State, entitled under article 48, paragraph 1, to invoke the responsibility of another State, to take lawful measures against that State to ensure cessation of the breach and reparation in the interest of the injured State or of the beneficiaries of the obligation breached.

States, then, can retaliate against a state that violates an obligation owed to the international community - an erga omnes norm.

What are the erga omnes norms? And do they support our theory? 
Human rights norms provide a strong case for erga omnes status. When a government violates the human rights of its own citizens, foreign states are not injured in the traditional international law sense. But clearly those states' citizens will feel some distress; plus there is the concern that human rights violations will destabilize the state and spill over the border. In the case of the worst human rights violations, it is plausible that other states genuinely object to them, so the risk that of pretextual intervention is more limited (compare, for example, violations of trade rules).

The norm against aggression would seem, at first sight, to be a classic two-party norm. However, the Kellogg-Briand pact and the UN charter, which outlawed aggressive war, were clearly motivated by multi-party concerns-namely, that a two-state war frequently draws in third parties, including allies and border states. Hence the concern for collective security in the UN charter.

Finally, the still-controversial norm against generalized environmental pollution-where, for example, pollution enters the ocean rather than a river that crosses a border-also reflects the theory, given that multiple states are injured and that the injury will rarely be detectable.

The worry that states might engage in predatory actions under the disguise of retaliation on account of violations of erga omnes norms seems to be addressed in Art. 49, which limits countermeasures. One problem with such approach is that sometimes only significant countermeasures will be sufficient to deter a violation of erga omnes norms - namely, when those violations bring significant benefits to the violator.

In sum, erga omnes norms facilitate collective enforcement of norms that create public goods, including the general rules of the international system, by making clear that certain aggressive acts that would otherwise appear to be violations of two-party norms are, in fact, permissible attempts to participate in collective action.

\section{A Note on Jus Cogens Norms}

Jus cogens, or peremptory, norms are norms of international law with which states must comply; unlike ordinary norms, they do not have their basis in consent. ${ }^{3}$ It would appear that all jus cogens norms must also be erga omnes norms: when a state violates a

\footnotetext{
${ }^{3}$ See ILM art. 40.
} 
jus cogens norm, all other states have the right to complain, and not just the state (if any) that is injured by the violation. Or, put differently, all states are, in a legal sense, injured by the violation.

It is not clear whether there is a meaningful difference between jus cogens norms and erga omnes norms. ${ }^{4}$ One might think that the difference is that erga omnes norms can, in principle, be changed by all states through a universal treaty, whereas jus cogens norms cannot be changed even by a universal treaty. However, one suspects that in practice, if all states agree to abolish a jus cogens norm, it will have no practical meaning or effect, even if it continues to hover in some ethereal precinct of natural law.

Another possible difference between these two types of norms is that states have an obligation to retaliate against states that violate jus cogens norms, whereas states have no obligation to retaliate against states that violate erga omnes norms; they only have the right. Article 41 of the ILM draft suggests as much:

Particular consequences of a serious breach of an obligation under this chapter

1. States shall cooperate to bring to an end through lawful means any serious breach within the meaning of article 40.

2. No State shall recognize as lawful a situation created by a serious breach within the meaning of article 40, nor render aid or assistance in maintaining that situation.

3. This article is without prejudice to the other consequences referred to in this part and to such further consequences that a breach to which this chapter applies may entail under international law.

Recall that by giving states a right to punish states that violate erga omnes norms, international law reduces, or at least avoids exacerbating, the problem of free riding when the violation of a norm injures many states rather than just one. The thinking behind the obligation to punish in the case of violations of jus cogens norms must be that such an

\footnotetext{
${ }^{4}$ For a lucid discussion, see Andreas L. Paulus, Jus Cogens in a Time of Hegemony and Fragmentation: An Attempt at a Re-appraisal, 74 Nordic Journal of International Law 297 (2005).
} 
obligation will further reduce the collective action problem, given states' reluctance to violate international law.

However, it seems doubtful that this distinction can hold up in practice. Creating a rule that states cannot free ride does not solve the free riding problem; it just pushes that problem back a stage. States must be willing to punish states that violate their obligation to punish states that violate jus cogens norms. However, for the same reason that states free ride on their obligation to punish states that violate jus cogens norms, they are likely to free ride on their obligation to punish states that violate their obligation to punish states that violate jus cogens norms. The free riding problem cannot be solved by fiat.

It seems likely that the difference between a jus cogens norm and an erga omnes norm is just that jus cogens norms are more "serious," that is, a greater concern to states. If all or nearly all human rights norms are erga omnes norms, only the most serioussuch as genocide, for example-are jus cogens norms. It may be that states are more willing to cooperate to address violations of jus cogens norms, than they are in the case of other erga omnes norms, just because, for those states, more is at stake when jus cogens norms are violated, so cooperation is more likely to be rational.

\section{Institutionalization}

It should be evident that two-party and erga omnes norms imply relatively low levels of cooperation. Two-party norms arise when two states engage in bilateral cooperation. Bilateral cooperation does not enable states to obtain multi-state public goods, and it is vulnerable to miscommunication and misunderstanding-as when one state reasonably believes that an action does not violate the norm and the other states reasonably believes that it does. In addition, bilateral cooperation is vulnerable to exogenous, even if temporary shocks. States may stop cooperating for the duration of the shock and then be unable to restart cooperation when the shock ends. Bilateral cooperation is also limited by states' discount factors.

Erga omnes norms arise when the violation of a norm that appears to hurt only one state in fact hurts various other states-in other words, when multistate cooperation can generate public goods. Multilateral cooperation suffers from all the difficulties of bilateral cooperation, but multilateral cooperation is even more difficult. The free-rider 
problem interferes with coordinated retaliation, and opportunities for good-faith disagreement that derails cooperation are more plentiful.

States have developed various methods for improving both types of cooperation. These methods have not overcome the fundamental constraints-such as low discount factors and other limits on cooperation. But they have helped overcome one particular problem: ambiguity about whether a particular act is a violation of a norm justifying retaliation, or is consistent with a norm. As noted above, this problem can be acute. Two states otherwise willing to cooperate may fall into a rut of conflict if one state in good faith interprets an act meant as compliance with a norm as in fact a violation. The first state retaliates; the second states sees the retaliation as an independent violation and thus retaliates as well; and so on.

Consider our migration example again. Suppose that $X$ encourages or compels some of its citizens to cross the border and settle on $Y$ 's territory. $X$ hopes to relieve population pressure and to create a base of support in $Y$. We might imagine that $X$ does not believe that this action constitutes a violation of the norm governing its relationship with $Y$. However, $Y$ might believe that this action is a violation. $Y$ retaliates by expelling the migrants or committing some other act that clearly violates the norm. $X$, in turns, retaliates against what it perceives to be an independent transgression. Eventually both sides close the border or even go to war, and all the earlier benefits of cooperation are lost.

How could such a misunderstanding take place? In principle, $X$ and $Y$ ought to cooperate in a manner that maximizes the surplus, and there will be an equilibrium in which they take actions that maximize the surplus, subject to the constraint of their discount factors. But suppose that $X$ and $Y$ are uncertain about each other's payoffs. $Y$ might believe, for example, that $X$ gains little through the forced migration, while $X$ might believe that $Y$ loses very little from it. If they each have private information about their own payoffs, it may be difficult for each state to credibly reveal what its own payoffs are. After all, $X$ will want to persuade $Y$ that it gains a lot from the migration, and $Y$ will want to persuade $X$ that it is hurt a great deal. Both states would gain, in the long run, if they could use an institution that could reliably determine each state's payoff and credibly reveal it to the other state. 
One traditional method for improving cooperation has been arbitration. Suppose that two states have a conflict, say, over the location of a border. The two states fail to resolve their dispute diplomatically. In terms of our model, the states disagree about whether a particular act (the movement of troops to a particular area in the neighborhood of an undemarcated border), counts as a violation or not. It may be that the norm can be derived from previous agreements of the states, or historical records that are hard to interpret and subject to multiple interpretations. If so, states that are otherwise willing to cooperate, indeed to continue their historic cooperation over the border, may appoint an arbitration panel to resolve the dispute. In this scenario, the state that loses the arbitration "cooperates" by complying with the decision and accepting the new border location, and "cheats" by rejecting the decision. The game then continues. There are complexities, to be sure. If the arbitrators are biased or incompetent, they might render a decision that is worse for the losing state than the loss of the gains from continued cooperation, leading it to refuse to comply. Indeed, the state may be able to make a credible case that the arbitrator erred, and therefore cooperation does not require compliance.

Arbitration had a number of limitations. The main problem was not so much that states could refuse to follow arbitral orders; states can always refuse to follow the rules. The problem was that arbitration panels serve only the interests of the states that establish them. The panels thus had little incentive to develop the jurisprudence of international law in a manner that benefits all states; indeed, often their opinions were secret. In addition, arbitration panels do not exploit economies of scale as judicial systems do. An appellate body, for example, can correct errors, but it is never worthwhile to set up an ad hoc appellate body to review the decision of an ad hoc arbitral panel.

The twentieth century has seen a burst of institution-building. Chief among the judicial institutions are the International Court of Justice, the WTO dispute resolution mechanism, the International Criminal Court, the European Court of Justice, and the European Court of Human Rights. Non-judicial institutions have included the United Nations, as well as countless regional and bilateral organizations. The judicial institutions can be understood as devices, like arbitration panels, for clarifying legal norms - that is, the type of behavior that counts as cooperative or predatory against the background 
cooperative arrangements of states-through the process of reliably determining and credibly revealing states’ payoffs from cooperative behavior.

How can these institutions overcome collective action problems? It is not clear that they can, but we need to start with a theory of some sort, and then we can critique that theory.

I will draw on Barry Weingast's theory of constitutionalism, ${ }^{5}$ one that he applies to domestic institutions, but which can also be applied to international relations. In Weingast's model, there are three players: a sovereign and two groups of citizens, group $A$ and group $B$. Weingast assumes that the sovereign can engage in any act if no group or only one group opposes him, but that the sovereign cannot overcome the joint opposition of both groups. If the sovereign seeks to maximize power, it will pursue a divide-andconquer strategy of crushing one group with the acquiescence of the other (which may well benefit from some of the spoils), and then turning against the second. To prevent such a strategy from succeeding, groups $A$ and $B$ must coordinate, with each agreeing to join the other in opposition to the sovereign whenever the sovereign takes action against one of the groups. A constitution will set out the limits of the sovereigns action and provide a focal point for $A$ and $B$ 's coordination.

This very general theory can be applied to international relations; indeed, it bears a strong resemblance to traditional balance-of-power theory, where two weaker states gang up against a larger state in order to prevent that state from dividing and conquering. However, we will assume that the "sovereign" is just an international institution. The institution has some international function-let's say that of clarifying the norms of international law. Left to its own devices, the institution might pursue a path that reflects the interests of its members and leaders, who might attempt to implement their ideological preferences, or the policy of a powerful state or group of states to which they feel allegiance. However, two states-state $A$ and state $B$ - can prevent the institution from engaging in improper behavior by jointly opposing it whenever it strays across

\footnotetext{
${ }^{5}$ Barry R. Weingast, The Political Foundations of Democracy and the Rule of Law, 91 Amer. Pol. Sci. Rev. 245 (1997). There is, of course, a vast international relations literature that investigates how international institutions can be sustainable in equilibrium; see, e.g., Robert O. Keohane, After Hegemony (1984).
} 
boundaries established in the treaty documents that created it. These rules provide the focal point for $A$ and $B$ 's coordinated response.

The theory provides only the barest thumbnail sketch of how international institutions could exist in equilibrium. One problem is that many states exist, and if $A$ and $B$ have an interest in keeping the institution within its original bounds, states $C, D$, and $E$ might have a different interest. They might support the institution's self-aggrandizement vis-à-vis $A$ and $B$, expecting to divide the spoils, whereupon the institution may turn on them. The collective action problem is not really solved, at least not without restrictive and unrealistic assumptions. ${ }^{6}$

\section{Constitutionalism}

Let me start by defining constitutionalism in the context of international relations. Suppose that state $X$ engages in a violation of international law that directly injures foreign citizen $Y$ : for example, the violation of a pollution treaty that results in $Y$ becoming ill. In the traditional view of international law, $Y$ would have recourse only to his own government. His government might or might not press $Y$ 's claim against state $X$ on $Y$ 's behalf. If the government chooses to do so, and obtains a remedy, the requirements of international law would be exhausted. $Y$ 's government might even fail to pass on any reparations to $Y^{7}$

In the constitutional approach, $Y$ would have a claim directly against $X$ for violating international law. The claim could be merely a political claim; conceivably, it could be legal as well. ${ }^{8}$ This claim might be heard by foreign states (or their courts) or by international institutions (such as international courts) that are not fully controlled by $X$. And $Y$ 's claim would not depend on his nationality; even a citizen of $X$ could bring this claim against his own government. Nationality is irrelevant: individuals anywhere in the

\footnotetext{
${ }^{6}$ A problem with Weingast's model as applied in its original domestic setting, as well: multiple groups exist within states, not just two or a small number; and the groups themselves can divide and reconstitute themselves into different groups in response to the sovereign's actions.

${ }^{7} Y$ might also be able to petition $X$ 's courts under $X$ 's domestic law if $X$ 's domestic law recognizes or incorporates the treaty obligation, but that need not be the case.

${ }^{8}$ For example, in the United States, some constitutional rules are enforceable as private rights of action; others are not. In most other countries, constitutional rules are generally not the source of private rights of action. For an interesting explanation for why private rights of action are used to enforce investment treaties but not trade treaties, see Alan O. Sykes, Public Versus Private Enforcement of International Economic Law: Standing and Remedy, 34 J. Legal Stud. 631 (2005).
} 
world can bring claims against states for violating their treaty obligations, and they might be able to pursue these claims in courts that are not fully or mainly controlled by those states.

Perhaps not everyone would call this system "constitutional," a word that can be given thicker or thinner meanings. ${ }^{9}$ The case for using this term in the present context is that here governments do not have the discretion to refuse to press the claim of an affected person. When that person is a citizen of the state ruled by that government, the government, in effect, agrees that an external institution will limit its authority over its own citizens.

What is the attraction of this approach? In essence, individuals are acting as whistleblowers. In the case of citizens, they, perhaps better than foreign states and international institutions, monitor the behavior of the government that regulates them, and can blow the whistle when that government violates its international obligations. The citizen will do so when he is injured by the violation, which is most likely to happen when the violation relates to human rights. In the case of foreigners, they also monitor the behavior of foreign states, and may be able to do so-because of advantages or incentives - better than their own state or international institutions. In addition, and perhaps more important, states wouldn't be able to refuse to press claims against other states with which they have a special cooperative relationship. States would have to treat all states, friend and foe, alike.

Is a constitutional approach sustainable in equilibrium? In principle, yes. The Weingast model can be used for this setting in the same way as we used it before. Suppose that $Y$ brings a claim against $X$ in a court. The court could be an international court, or it could be a court in a foreign county. The court rules in favor of $Y$ and issues an order to $X$. If $X$ fails to comply with the order, then the other states will retaliate. If $X$ complies with the order, the other states will not retaliate. In principle, such a system could be in equilibrium. Indeed, this model would describe domestic constitutional arrangement that Weingast's model originally applied to; it could also be used to describe various European judicial institutions.

\footnotetext{
${ }^{9}$ For some scholars, constitutionalism implies fundamental binding normative constraints on state action. See, e.g., Ernst-Ulrich Petersmann, Constitutional Functions and Constitutional Problems of International Economic Law (1991).
} 
Why haven't more ambitious international institutions been put into place? The model suggests that the various groups that can plausibly form and oppose transgressions by an international institution (the "sovereign" in the model) must gain from the arrangement, and must be able to agree on the norms. The more complex the setting, the more the uncertainty, and the more heterogeneous the preferences, the less likely it is that disparate groups will be able to agree on set of norms. Constitutionalism of this type also ignores states' interests in maintaining better relationships with some states than others; equal treatment may well be an impossible ideal in the state system as it currently exists.

\section{Coordination in the Absence of Sovereignty: International NGOs}

It is implicit in the discussion so far, but should be clear, that the sovereign state is not an essential condition of crossborder cooperation. In the first part, we assumed that individuals cooperate with individuals in other countries through intermediariesgovernments. But it is also possible for individuals to cooperate with individuals in other countries directly, with the governments playing no role or only a minimal role.

Suppose that individuals on either side of a border share a natural resource such as a lake. The individuals do best if pollution of the lake is kept to a minimum. It is certainly possible, as a matter of theory, that the individuals can cooperate with each other by agreeing not to overpollute and retaliating if others break the agreement. If there are many people, such an agreement might be impractical and unenforceable, but in many cases, there will not be too many people. States may play little or no role in enforcing an agreement.

A similar point can be made about groups. Individuals join groups and create institutions that deliver goods and services to their members even in the absence of state enforcement. Institutions can cooperate with each other, both within borders and across borders. Unions, religious groups, environmental organizations, and many other institutions forge links with similar groups in other countries, in some cases setting up federations. Corporations merge with foreign corporations or set up subsidiaries in foreign counties. These international NGOs have received a great deal of scholarly attention lately. ${ }^{10}$

${ }^{10}$ See, e.g., Bringing Transnational Relations Back In (Thomas Risse-Kappen ed. 1995). 
Why do international NGOs exist? Consider a multinational corporation. By crossing borders, a corporation gains various economies of scale. If it has invested a fixed amount in developing products, then it can earn high returns by selling this product in foreign countries, which will often involve establishing offices in those countries. It can also raise capital more cheaply by taking advantage of capital markets in different countries. Similarly, a public interest NGO will be attracted to multinational scale when its "product" is appealing in different countries, and it can raise money in different countries. If people in various countries $X, Y$, and $Z$, care about human rights practices in these countries and in other countries $A, B$, and $C$, then an international NGO like Human Rights Watch can spread the cost of monitoring activities across donors around the world.

I will briefly address three recurring questions about NGOs. (1) Do NGOs increase compliance with international law? (2) Do NGOs help generate international law? (3) Do NGOs provide a substitute for international law or international cooperation?

\subsection{NGOs and International Legal Compliance}

Several scholars have argued that NGOs enhance compliance with international law by pressuring states to comply with international law. ${ }^{11}$ Many NGOs monitor states’ claims that they comply with international law; these NGOs send agents to observe the behavior of government officials, take complaints, analyze data, and so forth. NGOs may be able to affect states' behavior by identifying violators and "shaming" those states, perhaps embarrassing government officials or raising the risk of international or domestic pressure. $^{12}$

However, as I have argued elsewhere, there is no reason to think that NGOs have an interest in ensuring the enforcement of international law as such. Some will pressure governments to comply with international law, while others will pressure governments to violate it. For example, exporters will pressure governments to comply with trade commitments, while domestic firms that compete with importers will pressure governments to violate them. ${ }^{13}$ Even limiting attention to public-interest NGOs, one should note that these NGOs usually have broader agendas than just that of ensuring that

\footnotetext{
${ }^{11}$ See, e.g., Harold Hongju Koh, Bringing International Law Home, 35 Hous. L. Rev. 623 (1998).

12 See, e.g., James C. Franklin, Shame on You: The Impact of Human Rights Criticism on Political Repression in Latin America, 52 Inter'l Stud. Q. 187 (2008).

${ }^{13}$ See Eric A. Posner, International Law and the Disaggregated State, 32 Fla. St. U. L. Rev. 797 (2005).
} 
states comply with international law. A human rights NGO, for example, cares about human rights violations even by states that have not ratified the relevant treaties; they care about changing international and national law. They care about practices that are not specifically prohibited by international law (like the death penalty). Thus, it is not clear that NGOs enhance compliance with international law.

\subsection{NGOs and the Creation of International Law}

Many scholars have argued that NGOs have helped create new international law. Frequently discussed examples include the heavy involvement of NGOs in the negotiation and ratification of the Landmines Treaty, and the statute of the International Criminal Court. Of course, none of this is new. NGOs have always been heavily involved in the negotiation of international law.

The argument is reasonable. International NGOs are distinctive precisely because they reflect the efforts of individuals in various states to affect the behavior of governments and people in other states; the creation of new international law is one way to accomplish this goal. However, from a normative perspective, the relevant question is not whether international NGOs contribute to new international law, but whether these contributions are desirable. This leads to the last question.

\subsection{NGOs, International Cooperation, and International Law}

Some scholars have worried that national policy outcomes will be influenced by institutions that are not politically accountable, indeed, by people who do not even live in the country in question and thus will not feel the impact of their activities. ${ }^{14}$

We can think of this issue from the perspective of interest group theory. Individuals in the United States and (say) India donate funds to an NGO such as Greenpeace that pressures both the American and the Indian government to change their environmental policies. Interest group theory (or one version of it) predicts that the American and Indian governments will tax their citizens and make transfers (in the form of policy outcomes) that the members of the NGO favor-in this example, environmentally friendly laws. As a result, both governments will supply environmental

\footnotetext{
${ }^{14}$ See the chapters in Risse, supra; Peter J. Spiro, The Democratic Accountability of Non-Governmental Organizations, 3 Chi. J. Int'l L. 161 (2002).
} 
goods at a higher level than that desired by the median (domestic) voter. In effect, domestic groups make alliances with foreign groups in order to put greater pressure on government than would otherwise be possible. From a public choice perspective, ordinary taxpayers will be the losers.

To be sure, international NGOs could also have desirable effects. Suppose, for example, that in United States and India, environmental public goods start off being undersupplied because of anti-environment interest groups such as industry. In principle, international environmental NGOs might offset this bias. However, interest group theorists usually argue that government policy will reflect a compromise between the interest groups that comes at the expense of voters. So it is hard to predict whether the involvement of international NGOs will improve or worse state policies. At best, we can predict that the dramatic decline of transportation and communication costs that has ushered in the current age of globalization should drive the growth of international NGOs, and particularly those that (1) have a cosmopolitan message (a message that appeals to people in different countries), and (2) appeal in particular to those in the rich west, who are in the best position to offer donations.

It is often argued that international NGOs weaken nation states, or at least are associated with the decline of the nation state. But scholars rarely spell out the mechanism. On a contrary view, states retain a monopoly on force; NGOs (except for criminal enterprises) do not have any ability to coerce people but must comply with the laws of the countries in which they operate; therefore, NGOs cannot compete with the governments of nation states. But what does seem clear is that international NGOs can, by providing a mechanism of influence by foreigners, create a wedge between the political preferences of citizens and the political outcomes of states. Citizens might respond by withdrawing their loyalty, or some of it, from the state. Unfortunately, it is unclear how international NGOs, lacking the ability to use force, can take up this slack, and supply public goods that states can no longer supply if citizens withdraw their loyalty. It is therefore not surprising that many people are hostile to international NGOs, and they may urge their governments to regulate or exclude them. 


\section{References}

FrankLIN, J.C. [2008], "Shame on You: The Impact of Human Rights Criticism on Political Repression in Latin America,” Inter'l Stud. Q., 52, 187.***

Keohane, R.O. [1984], After Hegemony: Cooperation and Discord in the World Political Economy, Princeton University Press: Princeton, NJ.

KoH, H.H. [1998], Bringing International Law Home, Hous. L. Rev., 35, 623-680.

PAulus, A.L. [2005], "Jus Cogens in a Time of Hegemony and Fragmentation: An Attempt at a Re-appraisal,” Nordic Journal of International Law, 74, 297-334.

Petersmann, E. [1991], Constitutional Functions and Constitutional Problems of International Economic Law, University Press: Fribourg, Switzerland.

Posner, E.A. [2005], "International Law and the Disaggregated State," Fla. St. U. L. Rev., 32, 797-842.

RAGAzZI, M. [1997], The Concept of International Obligations Erga Omnes, Clarendon Press: Oxford.

RisSE-KAPPEN, T. [1995], "Bringing Transnational Relations Back,” pp 3-33 in: RisSEKAPPEN, T (ed.), Non-State Actors, Domestic Structures and International Institutions, Cambridge University Press: Cambridge.

SPIRO, P.J. [2002], "The Democratic Accountability of Non-Governmental Organizations,” Chi. J. Int'l L., 3, 161-169.

SyKES, A.O. [2005], "Public Versus Private Enforcement of International Economic Law: Standing and Remedy,” J. Legal Stud, 34, 631-666.

Weingast, B.R. [1984], “The Political Foundations of Democracy and the Rule of Law," Amer. Pol. Sci. Rev., 91, 245-263.

ZEMANEK, K, [2000], "New Trends in the Enforcement of Erga Omnes Obligations," Max Planck UNYB, 4, 1-52.

Readers with comments should address them to:

Professor Eric A. Posner

University of Chicago Law School

1111 East 60th Street

Chicago, IL 60637

eposner@uchicago.edu 


\section{Chicago Working Papers in Law and Economics (Second Series)}

For a listing of papers 1-299 please go to Working Papers at http://www.law.uchicago.edu/Lawecon/index.html

300. Adam B. Cox, The Temporal Dimension of Voting Rights (July 2006)

301. Adam B. Cox, Designing Redistricting Institutions (July 2006)

302. Cass R. Sunstein, Montreal vs. Kyoto: A Tale of Two Protocols (August 2006)

303. Kenneth W. Dam, Legal Institutions, Legal Origins, and Governance (August 2006)

304. Anup Malani and Eric A. Posner, The Case for For-Profit Charities (September 2006)

305. Douglas Lichtman, Irreparable Benefits (September 2006)

306. M. Todd Henderson, Paying CEOs in Bankruptcy: Executive Compensation when Agency Costs Are Low (September 2006)

307. Michael Abramowicz and M. Todd Henderson, Prediction Markets for Corporate Governance (September 2006)

308. Randal C. Picker, Who Should Regulate Entry into IPTV and Municipal Wireless? (September 2006)

309. Eric A. Posner and Adrian Vermeule, The Credible Executive (September 2006)

310. David Gilo and Ariel Porat, The Unconventional Uses of Transaction Costs (October 2006)

311. Randal C. Picker, Review of Hovenkamp, The Antitrust Enterprise: Principle and Execution (October 2006)

312. Dennis W. Carlton and Randal C. Picker, Antitrust and Regulation (October 2006)

313. Robert Cooter and Ariel Porat, Liability Externalities and Mandatory Choices: Should Doctors Pay Less? (November 2006)

314. Adam B. Cox and Eric A. Posner, The Second-Order Structure of Immigration Law (November 2006)

315. Lior J. Strahilevitz, Wealth without Markets? (November 2006)

316. Ariel Porat, Offsetting Risks (November 2006)

317. Bernard E. Harcourt and Jens Ludwig, Reefer Madness: Broken Windows Policing and Misdemeanor Marijuana Arrests in New York City, 1989-2000 (December 2006)

318. Bernard E. Harcourt, Embracing Chance: Post-Modern Meditations on Punishment (December 2006)

319. Cass R. Sunstein, Second-Order Perfectionism (December 2006)

320. William M. Landes and Richard A. Posner, The Economics of Presidential Pardons and Commutations (January 2007)

321. Cass R. Sunstein, Deliberating Groups versus Prediction Markets (or Hayek’s Challenge to Habermas) (January 2007)

322. Cass R. Sunstein, Completely Theorized Agreements in Constitutional Law (January 2007)

323. Albert H. Choi and Eric A. Posner, A Critique of the Odious Debt Doctrine (January 2007)

324. Wayne Hsiung and Cass R. Sunstein, Climate Change and Animals (January 2007)

325. Cass. R. Sunstein, Cost-Benefit Analysis without Analyzing Costs or Benefits: Reasonable Accommodation, Balancing and Stigmatic Harms (January 2007)

326. Cass R. Sunstein, Willingness to Pay versus Welfare (January 2007)

327. David A. Weisbach, The Irreducible Complexity of Firm-Level Income Taxes: Theory and Doctrine in the Corporate Tax (January 2007)

328. Randal C. Picker, Of Pirates and Puffy Shirts: A Comments on "The Piracy Paradox: Innovation and Intellectual Property in Fashion Design” (January 2007)

329. Eric A. Posner, Climate Change and International Human Rights Litigation: A Critical Appraisal (January 2007)

330. Randal C. Picker, Pulling a Rabbi Out of His Hat: The Bankruptcy Magic of Dick Posner (February 2007)

331. Bernard E. Harcourt, Judge Richard Posner on Civil Liberties: Pragmatic (Libertarian) Authoritarian (February 2007) 
332. Cass R. Sunstein, If People Would Be Outraged by Their Rulings, Should Judges Care? (February 2007)

333. Eugene Kontorovich, What Standing Is Good For (March 2007)

334. Eugene Kontorovich, Inefficient Customs in International Law (March 2007)

335. Bernard E. Harcourt, From the Asylum to the Prison: Rethinking the Incarceration Revolution. Part II: State Level Analysis (March 2007)

336. Cass R. Sunstein, Due Process Traditionalism (March 2007)

337. Adam B. Cox and Thomas J. Miles, Judging the Voting Rights Act (March 2007)

338. M. Todd Henderson, Deconstructing Duff \& Phelps (March 2007)

339. Douglas G. Baird and Robert K. Rasmussen, The Prime Directive (April 2007)

340. $\quad$ Cass R. Sunstein, Illusory Losses (May 2007)

341. Anup Malani, Valuing Laws as Local Amenities (June 2007)

342. David A. Weisbach, What Does Happiness Research Tell Us about Taxation? (June 2007)

343. David S. Abrams and Chris Rohlfs, Optimal Bail and the Value of Freedom: Evidence from the Philadelphia Bail Experiment (June 2007)

344. Christopher R. Berry and Jacob E. Gersen, The Fiscal Consequences of Electoral Institutions (June 2007)

345. Matthew Adler and Eric A. Posner, Happiness Research and Cost-Benefit Analysis (July 2007)

346. Daniel Kahneman and Cass R. Sunstein, Indignation: Psychology, Politics, Law (July 2007)

347. Jacob E. Gersen and Eric A. Posner, Timing Rules and Legal Institutions (July 2007)

348. $\quad$ Eric A. Posner and Adrian Vermeule, Constitutional Showdowns (July 2007)

349. Lior Jacob Strahilevitz, Privacy versus Antidiscrimination (July 2007)

350. Bernard E. Harcourt, A Reader's Companion to Against Prediction: A Reply to Ariela Gross, Yoram Margalioth, and Yoav Sapir on Economic Modeling, Selective Incapacitation, Governmentality, and Race (July 2007)

351. Lior Jacob Strahilevitz, “Don’t Try This at Home”: Posner as Political Economist (July 2007)

352. Cass R. Sunstein, The Complex Climate Change Incentives of China and the United States (August 2007)

353. David S. Abrams and Marianne Bertrand, Do Judges Vary in Their Treatment of Race? (August 2007)

354. $\quad$ Eric A. Posner and Cass R. Sunstein, Climate Change Justice (August 2007)

355. David A. Weisbach, A Welfarist Approach to Disabilities (August 2007)

356. David S. Abrams, More Time, Less Crime? Estimating the Deterrent Effect of Incarceration using Sentencing Enhancements (August 2007)

357. Stephen J. Choi, G. Mitu Gulati and Eric A. Posner, Professionals or Politicians: The Uncertain Empirical Case for an Elected Rather than Appointed Judiciary (August 2007)

358. Joseph Bankman and David A. Weisbach, Consumption Taxation Is Still Superior to Income Taxation (September 2007)

359. Douglas G. Baird and M. Todd Henderson, Other People’s Money (September 2007)

360. William Meadow and Cass R. Sunstein, Causation in Tort: General Populations vs. Individual Cases (September 2007)

361. removed by author

362. Richard McAdams, Reforming Entrapment Doctrine in United States v. Hollingsworth (September 2007)

363. M. Todd Henderson, From Seriatim to Consensus and Back Again: A Theory of Dissent (October 2007)

364. Timur Kuran and Cass R. Sunstein, Availability Cascades and Risk Regulation (October 2007)

365. David A. Weisbach, The Taxation of Carried Interests in Private Equity (October 2007)

366. Lee Anne Fennell, Homeownership 2.0 (October 2007)

367. Jonathan R. Nash and Rafael I. Pardo, An Empirical Investigation into Appellate Structure and the Perceived Quality of Appellate Review (October 2007)

368. Thomas J. Miles and Cass R. Sunstein, The Real World of Arbitrariness Review (November 2007)

369. Anup Malani, Maciej F. Boni, Abraham Wickelgren, and Ramanan Laxminarayan, Controlling Avian Influenza in Chickens (November 2007)

370. Richard H. McAdams, The Economic Costs of Inequality (November 2007) 
371. Lior Jacob Strahilevitz, Reputation Nation: Law in an Era of Ubiquitous Personal Information (November 2007)

372. Thomas J. Miles and Cass R. Sunstein, The New Legal Realism (December 2007)

373. M. Todd Henderson, Everything Old Is New Again: Lessons from Dodge V. Ford Motor Company (December 2007)

374. Jonathan Remy Nash, Economic Efficiency versus Public Choice: The Case of Property Rights in Road Traffic (December 2007)

375. Edward L. Glaeser and Cass R. Sunstein, Extremism and Social Learning (December 2007)

376. Stephen J. Choi, G. Mitu Gulati, and Eric A. Posner, Are Judges Overpaid?: A Skeptical Response to the Judicial Salary Debate (December 2007)

377. Eric A. Posner, Does Political Bias in the Judiciary Matter?: Implications of Judicial Bias Studies for Legal and Constitutional Reform (January 2008)

378. Susan Bandes, The Heart Has Its Reasons: Examining the Strange Persistence of the American Death Penalty (January 2008)

379. $\quad$ Susan Bandes, After Innocence: Framing Wrongful Convictions (January 2008)

380. Jacob E. Gersen and Ann Joseph O’Connell, Deadlines in Administrative Law (January 2008)

381. Richard A. Epstein, The Property Rights Movement and Intellectual Property (January 2008)

382. Richard A. Epstein, Some Reflections on Custom in the IP Universe (January 2008)

383. Richard A. Epstein, Decentralized Responses to Good Fortune and Bad Luck (January 2008)

384. Richard A. Epstein, How to Create — or Destroy—Wealth in Real Property (January 2008)

385. Richard A. Epstein, The Human and Economic Dimensions of Altruism: The Case of Organ Transplantation (January 2008)

386. Cass R. Sunstein, Adolescent Risk-Taking and Social Meaning: A Commentary (January 2008)

387. Cass R. Sunstein and Adrian Vermeule, Conspiracy Theories (January 2008)

388. Ariel Porat, Expanding Restitution: Liability for Unrequested Benefits (January 2008)

389. Randal C. Picker, Twombly, Leegin and the Reshaping of Antitrust (February 2008)

390. Alon Harrel and Ariel Porat, Aggregating Probabilities across Offences in Criminal Law (March 2008)

391. John Bronsteen, Christopher Buccafusco, and Jonathan Masur, Hedonic Adaptation and the Settlement of Civil Lawsuits (March 2008)

392. Randal C. Picker, Fair Use v. Fair Access (March 2008)

393. Jonathan S. Masur, Process as Purpose: Administrative Procedures, Costly Screens, and Examination at the Patent Office (March 2008, revised July 2008)

394. Eric A. Posner, Human Welfare, Not Human Rights (March 2008)

395. Lee Anne Fennell, Slices and Lumps, 2008 Coase Lecture (March 2008)

396. Eric A. Posner, Fault in Contract Law (March 2008)

397. Cass R. Sunstein, Is OSHA Unconstitutional? (March 2008)

398. Randal C. Picker, Take Two: Stare Decisis in Antitrust/The Per Se Rule against Horizontal PriceFixing (March 2008)

399. M. Todd Henderson and Anup Malani, Corporate Philanthropy and the Market for Altruism (April 2008)

400. Shyam Balganesh, Foreseeability and Copyright Incentives (April 2008)

401. Cass R. Sunstein and Reid Hastie, Four Failures of Deliberating Groups (April 2008)

402. M. Todd Henderson, Justin Wolfers and Eric Zitzewitz, Predicting Crime (April 2008)

403. Richard A. Epstein, Bell Atlantic v. Twombly: How Motions to Dismiss Become (Disguised) Summary Judgments (April 2008)

404. William M. Landes and Richard A. Posner, Rational Judicial Behavior: A Statistical Study (April 2008)

405. Stephen J. Choi, Mitu Gulati, and Eric A. Posner, Which States Have the Best (and Worst) High Courts? (May 2008)

406. Richard H. McAdams and Janice Nadler, Coordinating in the Shadow of the Law: Two Contextualized Tests of the Focal Point Theory of Legal Compliance (May 2008)

407. Cass R. Sunstein, Two Conceptions of Irreversible Environmental Harm (Mary 2008)

408. Richard A. Epstein, Public Use in a Post-Kelo World (June 2008)

409. Jonathan R. Nash, The Uneasy Case for Transjurisdictional Adjudication (June 2008)

410. Adam B. Cox and Thomas J. Miles, Documenting Discrimination? (June 2008) 
411. M. Todd Henderson, Alan D. Jagolinzer, and Karl A. Muller, III, Scienter Disclosure (June 2008)

412. Jonathan R. Nash, Taxes and the Success of Non-Tax Market-Based Environmental Regulatory Regimes (July 2008)

413. Thomas J. Miles and Cass R. Sunstein, Depoliticizing Administrative Law (June 2008)

414. Randal C. Picker, Competition and Privacy in Web 2.0 and the Cloud (June 2008)

415. Omri Ben-Shahar, The Myth of the "Opportunity to Read" in Contract Law (July 2008)

416. Omri Ben-Shahar, A Bargaining Power Theory of Gap-Filling (July 2008)

417. Omri Ben-Shahar, How to Repair Unconscionable Contracts (July 2008)

418. Richard A. Epstein and David A. Hyman, Controlling the Costs of Medical Care: A Dose of Deregulation (July 2008)

419. Eric A. Posner, Erga Omnes Norms, Institutionalization, and Constitutionalism in International Law (August 2008) 